\title{
Transmission systems in agricultural tractors marketed in Brazil
}

\author{
Daniela Herzog ${ }^{*}$ (D) José Fernando Schlosser $^{2}$ (1) Rovian Bertinatto $^{3}$ (i) \\ Marcelo Silveira de Farias $^{4}$ (iD) Leonardo Casali ${ }^{5}$ (D)
}

${ }^{1}$ Programa de Pós-graduação em Engenharia Agrícola (PPGEA), Universidade Federal de Santa Maria (UFSM), 97105-900, Santa Maria, RS, Brasil. E-mail: dani herzog@hotmail.com. "Corresponding author.

${ }^{2}$ Departamento de Engenharia Rural (DER), Centro de Ciências Rurais (CCR), Universidade Federal de Santa Maria (UFSM), Santa Maria, RS, Brasil.

${ }^{3}$ Programa de Pós-graduação em Engenharia Agrícola (PPGEA), Universidade Federal de Santa Maria (UFSM), Santa Maria, RS, Brasil. ${ }_{4}^{4}$ Departamento de Ciências Agronômicas e Ambientais (DCAA), Universidade Federal de Santa Maria (UFSM), Frederico Westphalen, RS, Brasil.

${ }^{5}$ Curso de Agronomia, Universidade Federal de Santa Maria (UFSM), Santa Maria, RS, Brasil.

ABSTRACT: In a tractor, the transmission system transmits the power generated in the engine to the driving wheels, hydraulic systems, and power take-off (PTO). There are several types of transmission systems available in the Brazilian market ranging from the simplest to the most advanced. Therefore, the objective of this study was to verify the different types of transmission systems present in 228 models of agricultural tractors produced and marketed in Brazil during 2019. The tractor models were grouped based on the engine power and the transmission systems were classified as sliding, partially synchronized, synchronized, semi powershift, full powershift, and continuously variable transmission (CVT). According to this classification, it was found that most tractors belonged to Class III (51.5-73.5 $\mathrm{kW}$ ) with 66 models in total. However, even with continuous modernization in this field and with tractors becoming increasingly independent from the operator, $66 \%$ of transmission systems are still mechanical. However, CVT systems, which are available only in tractors with an engine power above $117.7 \mathrm{~kW}$, are expected to be equipped on less powerful tractors in the coming decades.

Key words: agricultural mechanization, gearbox, power class.

Transmissões que equipam os tratores agrícolas comercializados no Brasil

RESUMO: Em um trator, o sistema de transmissão tem a função de transmitir a potência gerada no motor para as rodas motrizes, sistemas hidráulicos e tomada de potência (TDP). São diversos os tipos de transmissões disponíveis no mercado brasileiro, desde as mais simples até as de última geração. Neste sentido, o objetivo deste trabalho foi verificar os tipos de transmissões que equipam 228 modelos de tratores agricolas, produzidos e comercializados no Brasil, durante o ano de 2019. Os modelos de tratores foram agrupados em classes de potência e as transmissões classificadas em: deslizante; parcialmente sincronizada; sincronizada; Semi Powershift; Full Powershift; e CVT. Como resultado, verificou-se que, na Classe III $(51,5$ a 73,5 $\mathrm{kW})$ são ofertados o maior número de tratores, 66 modelos no total. Mesmo o trator acompanhando as constantes modernizações do campo e estando cada vez mais independente do operador, 66\% das transmissões ainda são mecânicas. Porém, há o surgimento da transmissão CVT que, mesmo de modo incipiente, disponível apenas nos tratores com potência acima de 117,7 kW, tende a equipar tratores menos potentes nas próximas décadas.

Palavras-chave: mecanização agrícola, caixa de marchas, classes de potência.

Agricultural tractors are considered as indispensable machines in rural areas because they are used in various agricultural operations. Moreover, they can transmit power via the power take-off (PTO) or hydraulic systems (MÁRQUEZ, 2012). However, these operations require energy. The engine transforms the chemical energy of the fuel into mechanical energy (mechanical work), which is then converted into useful work through the transmission system.

The transmission system consists of a set of mechanisms capable of receiving, transforming, and transmitting the power and torque of the engine to the driving wheels, hydraulic systems, and PTO. This occurs by modifying the angular speed of the engine and, consequently, the torque in the rest of 
the system using the gears coupling. The gearbox is the main component of the transmission system because it is responsible for most of these changes. According to RIBAS et al. (2010), the transmission systems of tractors marketed in Brazil, despite various commercial names, fall into two categories: mechanical and hydrostatic transmissions.

Mechanical transmissions have gears that move on grooved shafts to mesh with each other and are classified into sliding and synchronized gears. The main difference between them is that synchronizer rings standardize the rotation of gears in the synchronized gearbox, thereby facilitating gear changes even when the tractor is in motion, this is not possible in the sliding gearbox.

Synchronized transmissions can be partially synchronized with only some gears having synchronizer rings (usually gears within the same group). Although, synchronized transmissions allow gear changes when the tractor is in motion, the tractor stops or suffers a significant reduction in speed even when skilled operators press the clutch to change the gear when there is a higher traction demand. Thus, in such situations, both the transmission systems will perform the job satisfactorily.

In contrast, some hydrostatic transmissions are characterized by the presence of several clutch disc packs whose function is to shift gears by directing pressurized hydraulic fluid (RIBAS et al., 2010). This system is commonly called as load exchange because it enables gear shifts without engaging the clutch. Hence, it is called as powershift transmission.

Powershift transmission is classified into semi powershift and full powershift depending on the construction characteristics and degree of transmission automation. The semi powershift system has disc packs only for gears within a group. Here, groups are changed by pressing the clutch and moving a lever or using an electro-hydraulic clutch (button) by moving the selector lever. The full powershift system has disk packs for selecting both the gear and group while the tractor is operating, i.e., on load.

Modern automated gear management systems require the operator to decide only the engine speed, whereas the control panel is responsible for selecting the best gear depending on the engine load. Since the appearance of powershift transmissions, the increase in the number of gears has served to combine the engine and transmission, thereby improving the tractor performance and boosting productivity (LINARES et al., 2010).

The continuously variable transmission (CVT) is one of the most advanced technologies in terms of transmissions and is increasingly equipped in agricultural tractors marketed in Brazil. In this transmission, there are no gears, i.e., the transmission ratios are infinite (among the ratios for which the tractor was designed, e.g., the combinations for the speed range from $\left.0-50 \mathrm{~km} \mathrm{~h}^{-1}\right)$. The engine speed changes constantly in accordance with the need of the transmission to maintain a constant tractor working speed.

CVT improves the use of engine power owing to the joint management of the engine and transmission via electronic systems. Additionally, it provides more comfortable operating conditions for the operator (ALONSO, 2014). Furthermore, CVTs enable working at lower rotations and adequate speeds, resulting in high fuel efficiency during agricultural operations as long as there is no overload of reducing the torque reserve of the engine (FARIAS et al., 2017).

To summarize, transmissions have evolved considerably in recent years. Therefore, the objective of this study was to verify the different types of transmissions in 228 models of agricultural tractors produced and marketed by 20 manufacturers in Brazil in 2019.

The data were collected from the technical information available on the website of the manufacturer. The transmissions were classified into: sliding, partially synchronized, synchronized, semi powershift, full powershift, and CVT. To explore the distribution of different types of transmissions based on engine power, the tractor models were grouped according to the classification proposed by FARIAS et al. (2016) into: Class I $(\leq 22.1 \mathrm{~kW})$, Class II $(22.1-51.5 \mathrm{~kW})$, Class III $(51.5-73.5 \mathrm{~kW})$, Class IV (73.5-117.7 kW), Class V (117.7-183.9 kW), Class VI (183.9-294.2 kW), and Class VII ( $\geq 294.2 \mathrm{~kW})$.

From figure 1A, it can be observed that 66 models in the Brazilian market belonged to Class III. Tractors in this power range are considered to be versatile, i.e., they are suitable for operations with different traction demands and working speeds. Thus, the sale of these models is greater and, consequently, there is a greater variety offered by the manufacturers.

Even with the continuous modernization in this field and tractors becoming increasingly independent from the operator, $66 \%$ of transmission systems are still mechanical (Figure 1B) with the synchronized type being the main transmission system reported in most tractors. This can be explained by the high efficiency of mechanical transmissions compared to hydrostatic transmissions, i.e., a greater capacity to transmit with fewer losses (MÁRQUEZ, 2012). 


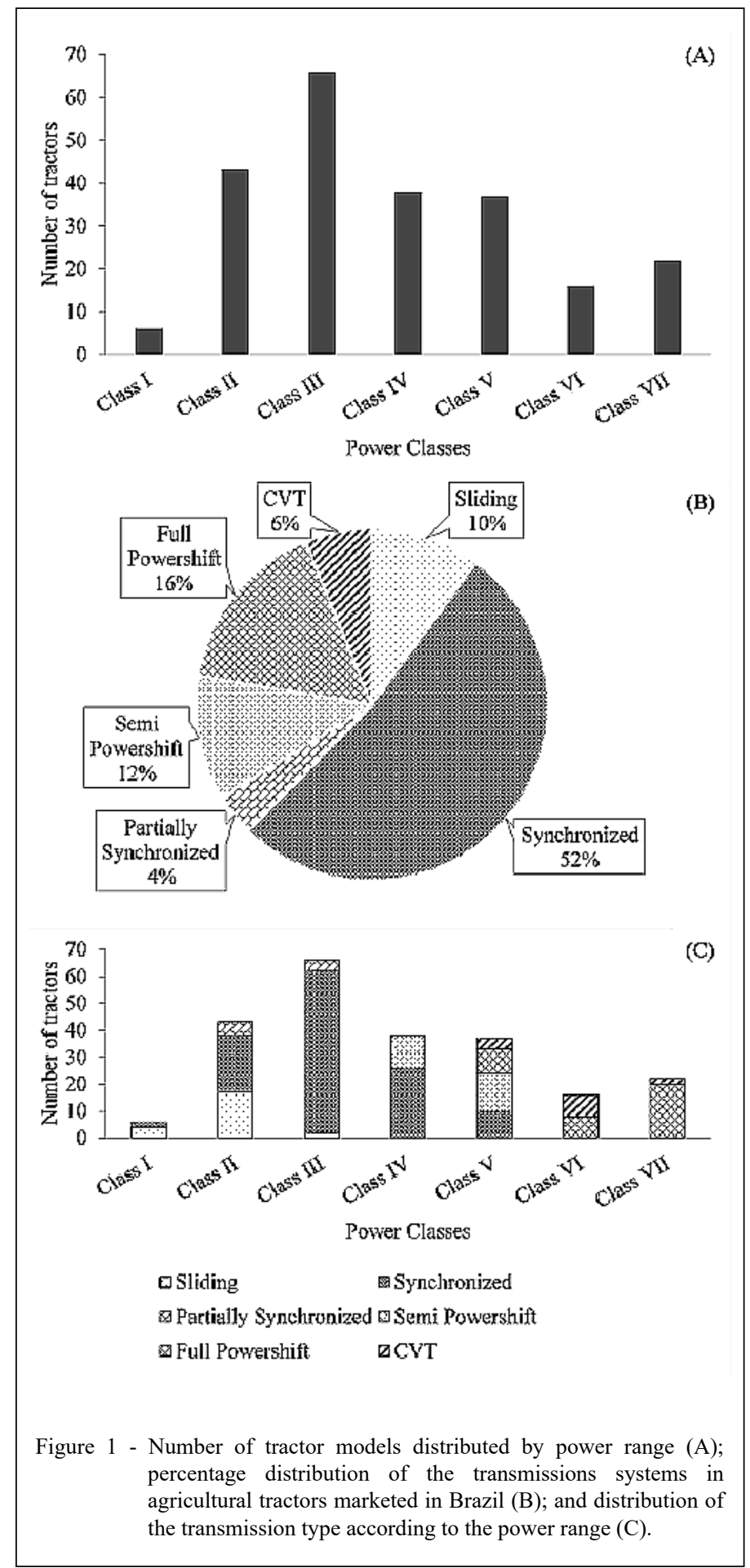

Additionally, the popularity of mechanical transmissions in low-power models may be related to the low production cost because the final cost of the product increases based on the transmission technology used. This may also be associated with government incentive programs for the acquisition of new tractors, mainly for small farmers and family farming, where the subsidized models are those with 
minimum specifications. Furthermore, tractors are priced based on engine power, which makes it more difficult to dilute the price of a high-end transmission system on a low-power tractor.

However, by comparatively analyzing the data obtained herein with that of the study conducted by RIBAS et al. (2010), it was observed that the number of models with hydrostatic transmissions has been increasing over the years. Consequently, there was a significant decrease in the number of sliding transmissions in high-power models. In 2010, hydrostatic transmissions accounted for $21 \%$ of the total available models, currently this number stands at $34 \%$.

The distribution of transmission type according to power range is shown in figure $1 \mathrm{C}$. Sliding and partially synchronized transmissions were only used in models with power below 73.5 $\mathrm{kW}$. Thus, there is a predominance of hydrostatic transmission systems in tractors with engine power above $183.9 \mathrm{~kW}$. Comparatively, 10 years ago, hydrostatic transmissions were equipped on all tractors with engine power of $148 \mathrm{~kW}$ and above (RIBAS et al., 2010).

Furthermore, CVT systems were used in tractors with engine power above 117.7 $\mathrm{kW}$. Nevertheless, there are 14 models with this transmission system and it is found in $50 \%$ of Class VI tractors (183.9-294.2 kW). According to LINARES et al. (2010), in Europe, the CVT system has been well received by farmers owing to its advantages, such as comfort, ease of handling, and response to the most diverse needs.

Additionally, RIBAS et al. (2010) stated that even after a decade, there is no standardization of terminology in this field, which causes a confusion of technical and commercial terms. Therefore, the verification of the correct classification by agricultural machinery certifying laboratories remains the greatest challenge in the Brazilian agricultural tractor market.

Therefore, it is concluded that the predominance of the mechanical transmission system is gradually decreasing with the increase in the tractor power range. However, the semi and full powershift transmissions present the opposite behavior, i.e., making tractors more technologically advanced over the years. Although, incipient and available only in high-end tractors, CVT systems are expected to be available in less powerful tractors in the coming decades.

\section{ACKNOWLEDGEMENTS}

This study was financed in part by the Coordenação de Aperfeiçoamento de Pessoal de Nível Superior (CAPES), Brasil Finance Code 001. The authors are also grateful to the Conselho Nacional de Desenvolvimento Científico e Tecnológico (CNPq) for research productivity scholarship of the second author and scientific initiation scholarships.

\section{DECLARATION OF CONFLICT OF INTERESTS}

The authors declare no conflict of interest. The founding sponsors had no role in the design of the study; in the collection, analyses, or interpretation of data; in the writing of the manuscript, and in the decision to publish the results.

\section{AUTHORS' CONTRIBUTIONS}

All authors contributed equally for the conception and writing of the manuscript.

\section{REFERENCES}

ALONSO, M. J. G. Descripción y estudio técnico de las estrategias de conducción de los tractores Deutz-Fahr. 2014. 198f. Trabajo Fin de Carrera (Departamento de Ingeniería Rural) - Universidad Politécnica de Madrid, Escuela Técnica Superior de Ingenieros Agrónomos, Madrid, España.

FARIAS, M. S. et al. Evaluation of new agricultural tractors engines by using a portable dynamometer. Ciência Rural, v.46, n.5, p.820-824, 2016. Available from: <https:/www.scielo.br/pdf/ cr/v46n5/1678-4596-cr-46-05-00820.pdf>. Accessed: Oct. 12, 2020. doi: 10.1590/0103-8478cr20150406.

FARIAS, M. S. et al. Fuel consumption efficiency of an agricultural tractor equipped with continuously variable transmission. Ciência Rural, v.47, n.06, e20160814, 2017. Available from: <http://www. scielo.br/pdf/cr/v47n6/1678-4596-cr-47-06-e20160814.pdf >. Accessed: Apr. 19, 2020. doi: 10.1590/0103-8478cr20160814.

LINARES, P. et al. Design parameters for continuously variable power-split transmissions using planetaries with 3 actives shafts. Journal of Terramechanics, v.47, n.5, p.323-335, 2010. Available from: <https:/www.sciencedirect.com/science/article/abs/pii/ S0022489810000364>. Accessed: Apr. 19, 2020. doi: 10.1016/j. jterra.2010.04.004.

MÁRQUEZ, L. Tractores Agrícolas: Tecnología y Utilización. Madrid: B\&H Grupo Editorial, 2012. 844p.

RIBAS, R. L. et al. Transmissions present in agricultural tractors in Brazil. Ciência Rural, v.40, n.10, p.2206-2209, 2010. Available from: <http://www.scielo.br/pdf/cr/v40n10/ a734cr3645.pdf $>$. Accessed: Apr. 18, 2020. doi: 10.1590/S010384782010005000162 . 